\title{
Multimedia Whiteboard Animation Untuk Meningkatkan Kemampuan Problem Solving Pada Guru
}

\author{
Dian Wahyuningsih, Suyantiningsih \\ Teknologi Pendidikan, Fakultas IImu Pendidikan, \\ Universitas Negeri Yogyakarta
}

\section{Edcomtech}

Jurnal Kajian

Teknologi Pendidikan

Volume 5, No 2, Oktober 2020

$109-118$

Submitted 10-12-2019

Accepted 15-06-2020

Corresponding Author

Dian Wahyuningsih

dianw@uny.ac.id

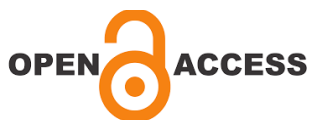

\begin{abstract}
Abstrak
Penelitian ini bertujuan mengembangkan multimedia whiteboard animation untuk meningkatkan kemampuan problem solving pada guru. Model pengembangan yang digunakan dalam penelitian ini yaitu model Borg and Gall dengan pendekatan deskriptif kualitatif. Subjek penelitian ini adalah guru-guru di Daerah Istimewa Yogyakarta (DIY). Produk hasil pengembangan telah dinilai oleh subject-matter expert dan media expert dengan hasil sangat baik. Tiga tahap uji coba telah dilakukan, meliputi: uji lapangan awal dengan skor 74,8\%, uji lapangan utama dengan skor $86,5 \%$, dan uji operasional dengan skor 83,5\%. Hasil implementasi produk terbukti dapat meningkatkan skor hasil belajar sebasar 38\%. Hasil kuesioner menunjukkan materi yang disajikan mudah untuk dipraktikkan. Kesimpulannya adalah multimedia whiteboard animation sangat baik digunakan untuk meningkatkan kemampuan problem solving pada guru.
\end{abstract}

Kata kunci: multimedia, whiteboard animation, problem solving

\begin{abstract}
This study aims to develop whiteboard animation multimedia to improve teachers' problem-solving skills. The development used the Borg and Gall model with a qualitative descriptive approach. The subjects of this research were teachers in the Special Region of Yogyakarta (DIY). The product developed has been rated by subject matter experts and media experts. Three stages of the trial have been carried out, including: the initial field test reached $74.8 \%$, the main field test with reached $86.5 \%$, and an operational test reached $83.5 \%$. The product implementation result proved that the multimedia increased by $41 \%$. The questionnaire showed that the material presented was easy to practice. From the data, it can be concluded that whiteboard animation multimedia that have good qualification to improve teachers problemsolving skill.
\end{abstract}

Keywords: multimedia, whiteboard animation, problem solving 


\section{LATAR BELAKANG}

Problem solving adalah suatu kemampuan di mana seseorang dapat menyelesaikan masalah dengan cara berpikir logis dan sistematis dalam waktu yang bersamaan. Guru sebagai ujung tombak pembelajaran di kelas, harus memiliki keterampilan tersebut agar dapat meningkatkan kualitas pembelajarannya. Kemampuan problem solving merupakan suatu kompetensi yang harus dikuasai guru terkait dengan tugas dan fungsinya. Dalam UU No.14 Tahun 2005 menjelaskan terdapat empat kompetensi yang harus dikuasai oleh guru, yaitu kompetensi profesional, pedagogik, kepribadian, dan sosial. Kemampuan problem solving ini tercermin dalam kompetensi pedagogik guru. Kompetensi pedagogik berkaitan dengan kemampuan pemahaman terhadap karakteristik dan potensi peserta didik serta perancangan, pelaksanaan dan evaluasi pembelajaran.

Problem solving berkenaan dengan kemampuan guru dalam melakukan evaluasi pembelajaran. Guru harus mampu merefleksi pembelajaran di kelasnya, menemukan masalah pembelajaran, memilih masalah yang menjadi wewenangnya untuk dapat diselesaikan, dan mencari solusi terbaik untuk menyelesaikannya. Oleh karena itu, dapat dikatakan bahwa kemampuan problem solving memiliki makna proses penyelesaian masalah dan hasil dari upaya penyelesaian masalah tersebut (Sulasamono, 2012: 162).

Problem solving yang dilakukan guru sebagai upaya melaksanakan evaluasi pembelajaran di kelas memiliki tujuan yang sama dengan PTK (Penelitian Tindakan Kelas). Tujuan PTK adalah perbaikan pada kualitas pembelajaran peserta didik yang meliputi proses dan hasil (Mulyasa, 2009: 10). PTK merupakan cara yang efektif membuat guru peka terhadap dinamika pembelajaran, lebih reflektif, dan kritis terhadap apa yang sudah dilakukan bersama siswanya di kelas. Melalui PTK guru dapat melakukan kajian mendalam terhadap apa yang terjadi di kelasnya secara sistematis berdasarkan masalah yang aktual dan faktual. Di sisi lain melalui PTK guru tidak hanya dianggap sebagai objek penerima pembaharuan, akan tetapi guru juga memiliki peran dan tanggung jawab dalam pengembangan pengatahuan dan keterampilan pembelajaran (Noorjanah, 2014: 97-114).

Guru dalam menjalankan tugas dan fungsinya terutama dalam bidang pengajaran, selalu dihadapkan dengan masalah pembelajaran yang terus menerus memerlukan penyelesaian. Masalah yang dapat diselesaikan dan menjadi wewenang guru sebagai pengelola pembelajaran adalah masalah yang terjadi di dalam kelas, seperti: pemanfaatan sumber belajar yang kurang tepat, strategi pembelajaran kurang efektif, atau rendahnya hasil belajar peserta didik. Akan tetapi terkadang guru kurang memahami cakupan wewenangnya dan masalah belajar yang timbul karenanya, sehingga dalam proses penemuan solusinya kurang tepat. Sebagai contoh mengenai alokasi anggaran pendidikan, administrasi sekolah, dan kebijakan pendidikan yang dikeluarkan oleh pemerintah.

Agar guru lebih peka melihat masalah pembelajaran yang terjadi di kelas dan memberi solusi yang tepat sebagai obat pada masalah yang terjadi di kelas, pemerintah menghimbau guru untuk dapat melakukan PTK. PTK memungkinkan guru untuk mengidentifikasi masalah pembelajaran di kelas, menentukan prioritas masalah dan solusinya yang lingkup penyelesaiannya berada dalam kewenangan guru. Melalui PTK guru juga dapat berpikir ilmiah dan sistematis dalam menemukan solusi dan menerapkan tindakan penyelesaian masalah yang ada. Dengan kemampuan penerapan PTK yang baik, secara otomatis guru juga memiliki kemampuan problem solving yang juga baik.

Data menunjukkan terdapat kurang lebih 61\% guru-guru di wilayah DIY (Daerah Istimewa Yogyakarta) yang diambil secara sampling dari lima kabupaten di DIY yaitu Kabupaten Sleman, Yogyakarta, Bantul, Kulon Progo, dan Gunung Kidul, tidak memahami esensi dan langkah penerapan PTK yang tepat. Walaupun cukup banyak juga guru di 
wilayah tersebut yaitu sekitar $67 \%$ sudah pernah menerapkan PTK untuk memperbaiki proses pembelajarannya (Suyantiningsih dkk: 2017). Kesulitan yang dialami kebanyakan guru adalah sulitnya membaca panduan penerapan PTK dari buku atau modul yang sudah ada. Buku atau modul teks yang ada di pasaran banyak yang menggunakan bahasa ilmiah dan baku sehingga sulit memahami makna yang tersirat.

Melalui observasi, sesungguhnya di pasaran banyak buku tentang PTK yang beredar dan bisa digunakan oleh guru sebagai panduan penerapan PTK, mulai dari buku teks, modul, atau panduan praktis semuanya tersedia. Akan tetapi, permasalahan yang lebih mendasar yang dialami oleh sebagian besar guru yaitu motivasi membaca yang rendah. Motivasi rendah tersebut muncul karena tidak adanya budaya membaca pada sebagian guru yang menjadi sampel.

Kultur membaca yang rendah tersebut diakibatkan oleh beberapa hal diantara: memang malas dan tidak tertarik membaca, tidak menemukan bahan bacaan yang menarik dan sesuai minat, tidak adanya waktu untuk membaca, dan guru lebih disibukkan dengan kegiatan administratif di sekolah dan urusan rumah tangga di rumah. Penelitian pendahuluan menunjukkan, sebanyak 54\% guru di wilayah Yogyakarta mengalami kesulitan memahami panduan penerapan PTK yang disajikan melalui teks karena rendahnya kultur membaca tersebut. Sebaliknya, budaya melihat atau menonton tayangan lebih banyak digemari oleh guruguru. Pesan atau informasi yang disajikan melalui gambar bergerak atau video lebih mudah diterima oleh guru.

Penggunaan teknik whiteboard animation dirasa tepat sebagai strategi untuk delivery materi karena guru dapat melihat tayangan materi yang dianimasikan dengan tanpa sadar juga diajak untuk membaca, karena animasi tersebut sebagian berupa gambar sebagian berupa teks. Kultur membaca juga berhubungan dengan kemampuan membaca dan kemampuan membaca ini bisa ditingkatkan melalui kegiatan yang menyenangkan diantara membaca materi pada multimedia interaktif di komputer, atau bisa juga membaca melalui game di komputer (Joe Lio Tjoe, 2013:24).

Selain masalah mengenai budaya baca, lebih lanjut data penelitian awal menunjukkan alasan mengenai kesulitan guru menerapkan PTK adalah sebagai berikut: 1) tidak ada waktu dengan persentase $37 \%, 2$ ) tidak memiliki motivasi meneliti/memperbaiki praktik pembelajaran dengan persentase $14 \%$, serta 3 ) referensi yang monoton dengan persentase $11 \%$.

Setelah memahami kondisi di atas, dapat disimpulkan bahwa kesulitan guru dalam menguasai kemampuan problem solving diakibatkan oleh tidak terbiasa guru untuk melakukan PTK dengan prosedur yang benar. Padahal dengan melaksanakan PTK keterampilan dalam problem solving dapat diakuisisi dengan baik oleh guru, seperti melakukan prosedur penentuan masalah hingga penerapan solusinya secara sistematis danilmiah. Keengganangurudalammelakukan PTK juga disebabkan karena media yang tersedia sebagai wahana belajar kurang sesuai degan keinginan dan karakteristik guru. Untuk mendorong motivasi guru dalam menerapkan PTK, diperlukan media yang secara konten mampu memberikan pemahaman terkait prosedur yang benar dalam PTK dan secara bentuk medianya diperlukan media yang tidak hanya menghadirkan teks, lebih konkret dalam bentuk tayangan video atau animasi dan guru memiliki kontrol penuh dalam menggunakannya.

Olehkarenaitu, tepatkiranya dikembangkan multimedia whiteboard animation yang berisi materi PTK untuk meningkatkan kemampuan problem solving pada guru. Mayer (2009) menjelaskan multimedia secara sederhana diartikan sebagai koordinasi pesan verbal dan gambar, sedangkan multimedia interaktif adalah multimedia yang meletakan kendali sistemnya pada pengguna, sehingga pengguna dapat menggunakan sesuai irama belajarnya. Sunarto (2007) menambahkan bahwa bentuk multimedia interaktif yang bisa digunakan untuk keperluan pembelajaran meliputi: drill and practice, tutorial, simulation, edutainment, dan problem solving. 
Hal yang menjadi ciri khas multimedia yang dikembangkan adalah menggunakan video animasi whiteboard untuk menyajikan materinya. Whiteboard animation sebetulnya hampir mirip dengan motion graphic, di mana motion graphic sendiri diartikan sebagai penggabungan dari berbagai bentuk artisitik digital yang berbasis visual meliputi foto, gambar, ilustrasi, grafik, dan sebagainya yang dikombinasikan dengan musik (Purwanti, 2015: 195). Perbedaan animasi yang dihasilkan antara motion graphic dengan whiteboard animation adalah selain software yang digunakan berbeda juga pada hasil akhirnya. Whiteboard animation dibuat seolah-olah objek dibuat melalui coretan pada papan tulis. Uniknya proses coret-mencoret tersebut merupakan bagian dari animasi yang dihasilkan.

Whiteboard animation atau dikenal dengan istilah video scribe, sketch video, dan explainer video merupakan teknik pembuatan video animasi melalui simbol dan karakter yang khas dari whiteboard (papan tulis). Melalui teknik tersebut media yang dihasilkan memenuhi syarat kepraktisan, kemudahan penggunaan, efisiensi waktu belajar, dan memberikan manfaat yang besar dalam mencapai hsil belajar (Yudha dkk, 2016: 153-160). Lebih lanjut Silmi dan Rachmadiyanti (2018:486-495) menjelaskan secara umum media yang dikembangkan dengan teknik whiteboard animation selain mampu menyampiakan pesan juga berfungsi untuk menumbuhkan minat belajar karena kemenarikannya.

Berdasarkan penjelasan di atas, pengembangan multimedia whiteboard animation diharapkan dapat digunakan oleh guru, terutama di wilayah DIY untuk meningkatkan kemampuannya dalam melakukan problem solving secara tepat.

\section{METODE PENELITIAN}

Penelitian ini mengadaptasi model research and development dari Borg and Gall. Berdasarkan model tersebut terdapat 10 tahap yang harus dilalui untuk mengembangkan produk (1989). Berikut merupakan gambar langkah pengembangan model tersebut:

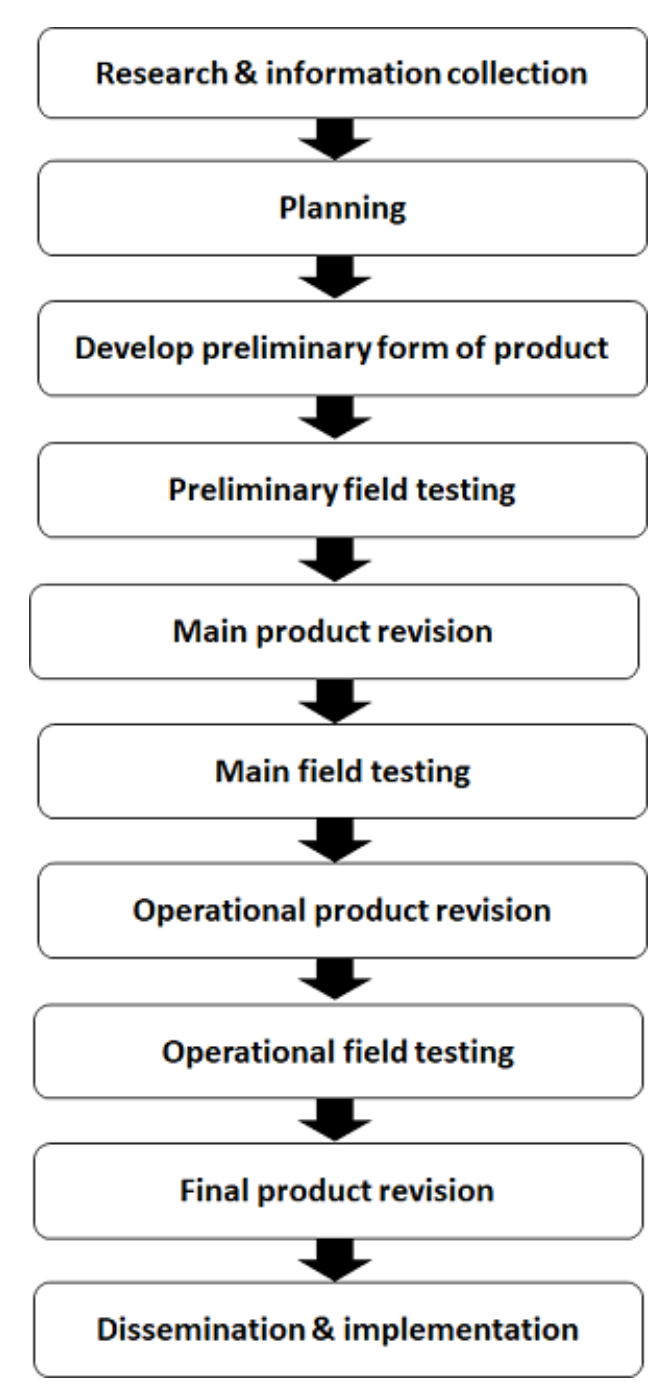

Gambar 1. Tahap Penelitian Pengembangan

Subjek penelitian ini adalah guru-guru yang diambil secara sampel dari lima kabupaten di Daerah Istimewa Yogyakarta (DIY) yaitu kabupaten Sleman, Yogyakarta, Bantul, Kulon Progo, dan Gunung Kidul. Teknik sampling yang digunakan adalah cluster random sampling, di mana sampel di ambil secara acak asal mencakup lima kabupaten di DIY dan meliputi jenjang pendidikan dasar hingga menengah. Guru yang menjadi sampel penelitian berjumlah 41 orang dengan mayoritas berjenis kelamin perempuan. Sampel mengajar dari berbagai jenjang pendidikan mulai dari TK (Taman Kanak-Kanak) hingga menengah atas, namun sekitar 50\% mengajar pada jenjang SMA/ SMK dengan bidang yang diajar bervariasi. Instrumen yang digunakan untuk penelitian 
ini meliputi kuesioner dan tes, sedangkan data penelitian dianalisis secara deskriptif kualitatif. Data hasil uji coba dihitung dengan rumus sebagai berikut:

$$
\text { Skor Akhir }=\frac{\text { Skor yang perolehan }}{\text { Skor tertinggi }} \times 100 \%
$$

Untuk mengetahui level kelayakan multimedia dan memberikan makna pada data yang diperoleh, konversi nilai diadaptasi dari Arikunto (2013) dapat dilihat pada tabel berikut ini:

Tabel 1. Konversi Nilai

\begin{tabular}{ccc}
\hline $\begin{array}{c}\text { Persentase } \\
\text { Pencapaian }\end{array}$ & Kualifikasi & Keterangan \\
\hline $76 \%-100 \%$ & Sangat Baik & Tidak perlu revisi \\
$51 \%-75 \%$ & Baik & Tidak perlu revisi \\
$26 \%-50 \%$ & Kurang Baik & Perlu revisi \\
$0 \%-25 \%$ & Tidak Baik & Perlu revisi \\
\hline
\end{tabular}

\section{HASIL DAN PEMBAHASAN}

Pengembangan multimedia whiteboard animation untuk meningkatkan kemampuan problem solving pada guru, mengikuti tiap langkah penelitian R \& D dari Borg and Gall. Langkah pertama yaitu research and information collection atau pencarian dan pengumpulan data. Penelitian pendahuluan untuk mencari data awal dilakukan melalui FGD (Focus Group Discussion) dengan 32 guru yang dibagi menjadi tiga grup dari jenjang sekolah dasar hingga menengah atas. FGD dipilih agar dapat memunculkan informasi mengenai masalah, kebutuhan, hingga sudut pandang dari peserta dalam waktu yang relatif cepat, sehingga permasalahan yang spesifik dapat terungkap (Paramita \& Kristiana, 2013: 118). Data yang diperoleh mengerucut pada sulitnya guru menggunakan dan memahami sumber belajar berupa teks tentang langkah problem solving yang tepat berdasarkan masalah pembelajaran yang dihadapi di kelas.

Langkah kedua yaitu planning atau perencanaan. Dalam langkah ini kegiatan yang dilakukan adalah menyusun storyboard multimedia. Stroryboard berisi flowchart atau bagan alir multimedia dan naskah animasi whiteboard yang berisi materi PTK, lebih spesifik pada langkah penyelesaian masalah belajar di kelas. Pengembangan flowchart ini merupakan tahapan yang penting. Hal tersebut dikarenakan dalam desain produk ini, multimedia yang dihasilkan adalah meng-embeded-kan (menanamkan) animasi papan tulis (whiteboard animation) ke dalam bagian dan fungsi multimedia interaktif yang utuh. Oleh karena itu selain flowchart untuk multimedia dan skenario video animasi juga dikembangkan dalam tahap ini. Tahap ini juga dilakukan dengan mengkaji literatur mengenai PTK dan melakukan konsultasi kepada ahli media agar storyboard mudah diterjemahkan menjadi produk.

Langkah ketiga yaitu develop of preliminary form of product atau mengembangkan produk awal. Langkah ini dilakukan dengan menterjemahkan storyboard menjadi produk awal. Animasi papan tulis (whiteboard animation) dibuat menggunakan software Sparkol dan berisi materi mengenai PTK, sedangkan multimedia dikembangkan menggunakan Adobe Flash. Whiteboard animation yang berisi materi PTK menjadi salah satu komponen utama dalam multimedia karena berisi konten materi. Pada tahap ini dilakukan validasi kepada ahli materi dan ahli media. Hasil validasi ahli media menyatakan bahwa produk yang dikembangkan sudah memiliki kualifikasi sangat baik dengan persentase $82,5 \%$. Penilaian dari ahli media juga menyatakan bahwa produk memiliki kualifikasi sangat baik dengan persentase $85,7 \%$.

Langkah keempat yaitu preliminary filed testing yaitu uji coba lapangan awal. Subjek uji coba dalam tahap ini ialah 10 orang guru. Hasil penilaian pada tahap ini produk dinyatakan layak digunakan dengan persentase $74,8 \%$ dengan beberapa catatan untuk direvisi.

Langkah kelima yaitu main product revision atau revisi produk utama. Kegiatan ini dilakukan dengan merevisi produk berdasarkan hasil uji coba lapangan awal. Revisi yang dilakukan adalah memperbaiki 
layout menu utama multimedia, mengganti karakter dalam animasi whiteboard yang lebih sesuai dengan guru, mengganti karakter suara pada animasi whiteboard, kontras warna font, dan memperbaiki beberapa kalimat yang tertulis pada beberapa menu dalam multimedia seperti dalam perumusan capaian belajar. Mengenai penyusunan kalimat, Smaldino, et al (2015: 190) menjelaskan tiga hal yang harus diperhatikan dalam penyusunan kalimat/teks dalam suatu media, yaitu: 1) to persuade, yaitu bertujuan untuk mengubah sudut pandang pembaca, 2) to explain, untuk memperluas pemahaman, dan 3) to convey experience, yaitu untuk mengkomunikasikan pikiran, imajinasi, dan pengalaman kepada orang lain.

Langkah keenam yaitu main field testing atau uji coba lapangan utama. Sampel uji coba dalam tahap ini adalah 15 orang guru. Hasil uji coba lapangan utama ini menyatakan produk sangat layak digunakan dengan persentase $86,5 \%$ dengan beberapa catatan minor yang perlu diperbaiki.

Langkah ketujuh yaitu operational product revision atau revisi produk operasional. Kegiatan yang dilakukan pada tahap ini adalah merevisi produk berdasarkan masukan dari guru-guru. Revisi yang dilakukan adalah memperbesar ukuran font pada multimedia, menambah menu petunjuk belajar dan memisahkannya dengan petunjuk penggunaan multimedia. Ukuran font akan mempengaruhi komposisi tampilan multimedia secara keseluruhan. Font yang digunakan dalam multimedia direvisi menjadi ukuran antara 16 hingga 24 point tergantung pada penempatan teksnya.

Langkah kedelapan yaitu operational field testing atau uji coba lapangan operasional. Kegiatan yang dilakukan pada tahap ini adalah menguji produk pada sampel yang lebih luas. Sampel yang digunakan dalam tahap ini adalah 30 orang guru. Hasil yang diperoleh pada tahap ini adalah produk dinyatakan sangat layak digunakan dengan persentase $83,5 \%$. Hasil uji coba tahap ini dibandingkan dengan tahap sebelumnya menunjukkan sedikit penurunan. Akan tetapi, hal tersebut dapat diabaikan karena persentase penurunannya sangat kecil yaitu
$3 \%$ dan sampel yang digunakan lebih banyak, sehingga hasil penilaian lebih objektif.

Langkah kesembilan yaitu final product revision. Langkah ini merupakan revisi terakhir dari produk sebelum siap diimplementasikan ke lapangan. Terdapat revisi minor pada uji coba tahap akhir ini yaitu perbaikan pada kesalahan tipo grafis kalimat dalam multimedia. Selanjutnya produk dikemas dengan baik, digandakan, dan siap untuk didiseminasikan. Produk dikemas dalam CD dan flash disk dilengkapi dengan buku panduan penggunaannya.

Walaupun tiga langkah uji coba multimedia berikut revisinya sudah dilakukan, tetap saja desain yang paling pas untuk semua subjek penelitian belum tercapai seluruhnya. Hal tersebut dikarenakan subjek penelitian, dalam hal ini guru, memiliki variasi dan karakteristik yang beragam dari segi usia, kemampuan, pengalaman, bidang studi yang diampu, minat, jenjang sekolah di mana guru mengajar, dan lain sebagainya. Dengan demikian, terbukti bahwa karakteristik peserta belajar mempengaruhi hasil belajarnya (Budiningsih, 2007).

Langkah terakhir adalah diseminasi dan implementasi. Dalam tahap ini, produk yang sudah selesai dikembangkan kemudian disebarluaskan dan diimplementasikan kepada guru-guru untuk melihat peningkatan kemampuan problem solving pada guru. Problem solving yang dimaksud adalah pemecahan masalah terkait pembelajaran di kelas yang ditemui guru selama ini, di mana Chi \& Glaser dalam Matlin (1989) menjelaskan bahwa kemampuan problem solving merupakan kemampuan paling cerdas yang dimiliki oleh manusia.

Tahap implementasi dilakukan pada sampel sebanyak 41 orang guru dari lima kabupaten di DIY yang mewakili jenjang pendidikan dasar hingga menengah. Instrumen yang digunakan adalah tes dan angket. Hasil tes awal menunjukkan kemampuan problem solving guru sebelum menggunakan multimedia berada pada kualifikasi kurang baik dengan persentase $48 \%$. Setelah mempelajari multimedia selama kurang lebih dua minggu terjadi peningkatan kemampuan tersebut dengan persentase $86 \%$ 
dengan kualifikasi sangat baik. Secara praktis persentase kenaikan kemampuan problem solving guru sebesar $38 \%$. Hal tersebut bisa dilihat dari bagan berikut:

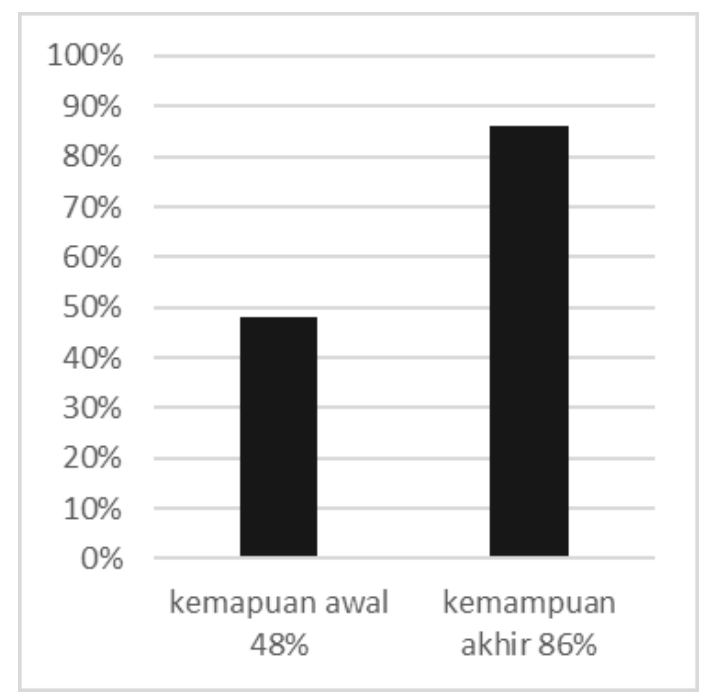

\section{Gambar 2. Kemampuan Problem solving}

Hasil angket mengenai kemampuan problem solving guru menunjukkan bahwa setelah mempelajari multimedia, pemahaman dan pandangan guru akan konsep masalah pembelajaran di kelas berubah. Semula masalah dipandang sangat rumit dan kompleks, berangsur-angsur para guru dapat mengerti cakupan masalah pembelajaran yang dapat ditanganinya sendiri. Hal tersebut memperjelas bahwa media juga dapat berfungsi sebagai alat persuasi yang baik, jika dirancang dengan kaidah desain pesan yang tepat (Smaldino et al, 2015: 190).

Materi yang disajikan mudah diterima oleh guru, terbukti dari sedikitnya revisi pada aspek ini. Hal tersebut dikarenakan penggunaan multimedia interaktif dapat memberikan pengalaman self-explanatory bagi guru karena digunakan mengikuti prinsip desain pembelajaran (Budiningsih, 2008). Karakter yang ditampilkan dalam animasi whiteboard cukup mudah diterima dan lebih disukai oleh guru karena lebih unik. Penggunaan gambar kartun atau karikatur dalam suatu media juga terbukti dapat meningkatkan perolehan belajar (Riyanto dkk, 2017: 18-25), karena dalam penjelasan materi, desainer dapat menganalogikan suatu tokoh atau karakter dengan mudah melalui gambar. Apalagi penggunaan software whiterboard animation yang sangat praktis, sehingga desainer tinggal memanfaatkan saja image yang ada sehingga lebih efisien.

Solusi yang ditawarkan oleh guru terhadap masalah yang muncul di kelas cukup realistis setelah mempelajari multimedia, sebagai contoh: sulitnya siswa menghafal bilangan pecahan, maka solusi yang ditawarkan guru adalah menggunakan metode menghafal. Kreativitas guru juga terlihat dari alternatif penyelesaian masalah yang diberikan. Untuk satu masalah setidaknya guru bisa mengidentifikasi dua hingga tiga alternatif penyelesaiannya. Hal tersebut sesuai dengan penjelasan Patnani (2013:140) bahwa orang yang kreatif ialah orang yang mampu melihat beberapa alternatif jawaban untuk menyelesaikan suatu permasalahan, bukan hanya satu saja.

Adapun spesifikasi produk hasil pengembangan yang membedakannya dengan produk lain yang sejenis adalah pada materi yang disajikan menggunakan teknik whiteboard animation. Adapun tampilan produk dapat dilihat pada gambar berikut ini:
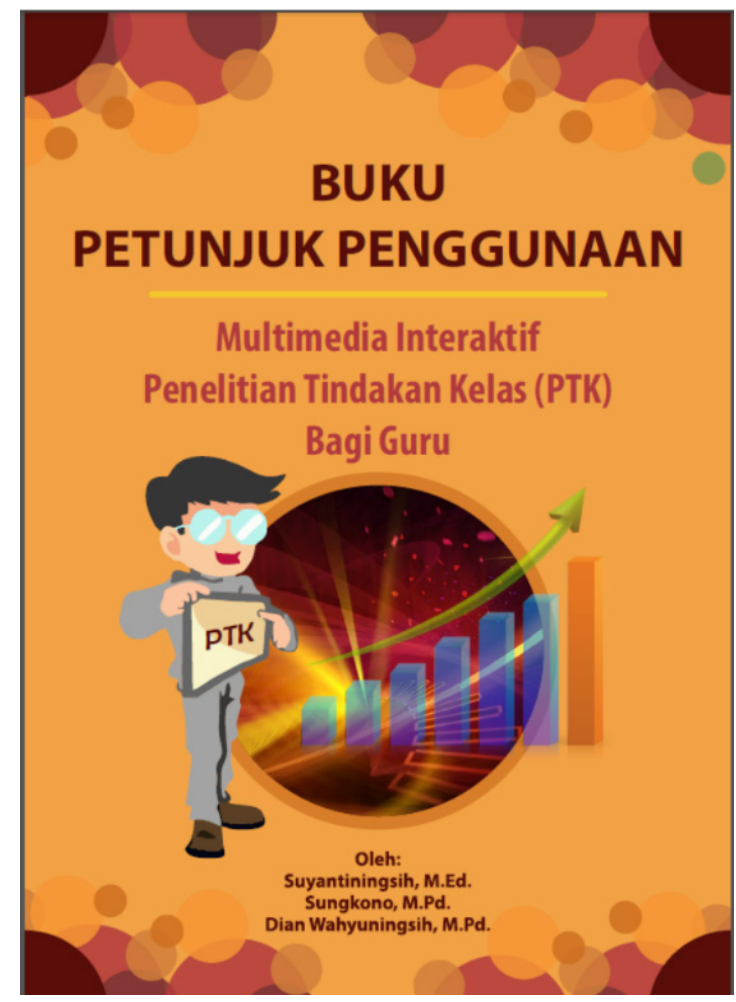

Gambar 3. Cover Petunjuk Penggunaan 


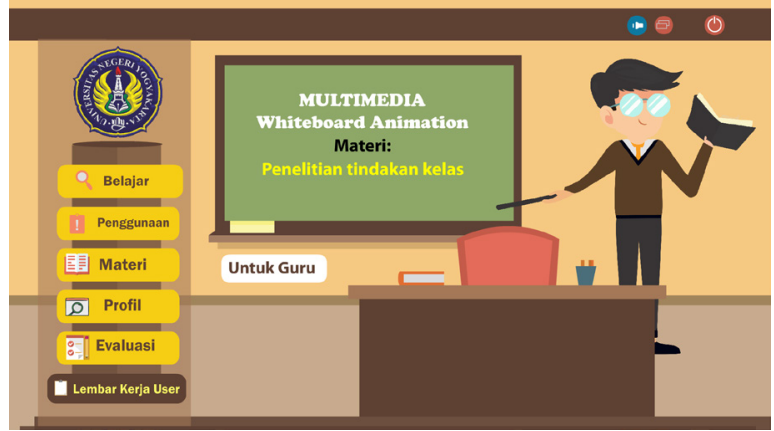

Gambar 4. Tampilan Menu Home

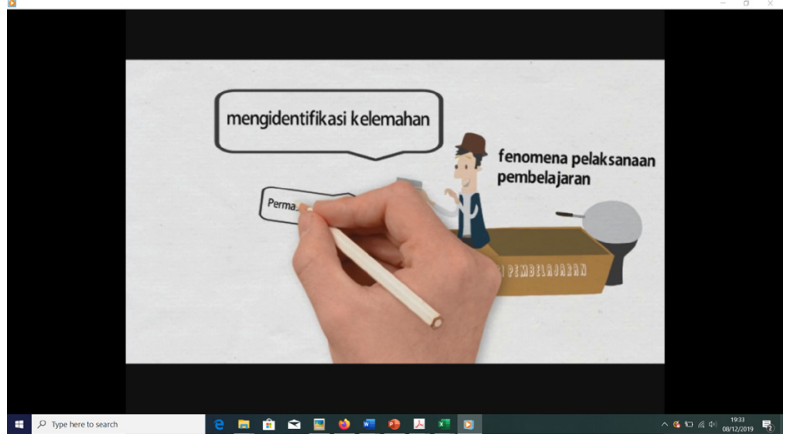

Gambar 5. Tampilan Materi

Untuk menghasilkan media yang layak oleh guru-guru di wilayah DIY. Kelayakan multimedia diperoleh melalui tiga tahap uji coba, yaitu: uji coba lapangan awal, uji coba lapangan utama, dan uji coba operasional. Dalam implementasinya, multimedia whiteboard animation terbukti dapat meningkatkan kemampuan problem solving pada guru sebesar $38 \%$.

Kemampuan pemecahan masalah merupakan salah satu keterampilan penting yang harus dikuasai oleh guru agar dapat mengajarkannya secara optimal kepada para siswa (Kaya (2017), Kozikoglu (2019). Untuk melatih pemecahan masalah dapat menggunakan beberapa metode seperti permainan (Mathew dkk, 2019). Selain itu kemampuan pemecahan masalah bagi guru juga dapat dilakukan menggunakan proses lesson study (Bradshaw, dkk 2017).

Dalam konteks yang lain kemampuan pemecahan masalah juga dapat dilakukan dalam bentuk pembelajaran berbasis kearifan lokal (Dewi, dkk 2017). Hal itu juga dapat dilakukan untuk melatih kemampuan komunikasi. Kinay \& Bagçeci (2016) menjelaskan bahwa kemampuan pemecahan masalah dapat diukur menggunakan penilaian autentik.
Pada era digital seperti saat ini, proses pembelajaran yang berorentasi pada peningkatan kemampuan berpikir tingkat tinggi dapat dirancang dalam model pembelajaran daring (Surahman, dkk, 2018). Bentuk implementasinya dapat menyajikan pembelajaran berbasis proyek secara berkelompok, hal itu dapat melatih kemampuan menganalisis dan menyelesaikan masalah yang ditemukan dalam proses pengembangan proyeknya (Surahman, dkk, 2019).

Untuk mencapai hasil pembelajaran yang berorientasi pada keterampilan berpikir tingkat tinggi dapat dilakukan dengan syarat para guru memiliki sikap yang positif terhadap kelebihan yang ditawarkan oleh teknologi yang berkembang saat ini (Alfindasari, 2014). Karena pada dasarnya pemecahan masalah sangat memungkinkan dilakukan dengan bantuan teknologi pembelajaran seperti yang dilakukan oleh (Car, dkk 2019, Chen, dkk 2019).

\section{SIMPULAN}

Kesimpulan yang dapat ditarik dari pelaksanaan penelitian ini adalah multimedia whiteboard animation yang dikembangkan melalui model R \& D dari Borg \& Gall dapat

Rekomendasi untuk penelitian selanjutnya adalah produk yang sudah dikembangkan bisa digunakan pada skala lebih luas (subjek lain di luar sampel) untuk mengetahui tingkat efektivitas program jika digunakan di tempat lain. Whiteboard animation ini dapat dikatakan sebagai teknik yang unik dan menarik selain itu proses pengembangannya relatif simpel. Pengembang bisa memadukannya dalam power point atau menjadi multimedia berbasis adobe flash seperti produk ini ataupun berdiri sendiri sebagai videoscribe. Pengembang juga bisa menggunakan teknik ini pada materi lainnya baik pada level disemua jenis pendidikan dan jenjang pendidikan yang tentunya tetap memperhatikan karakter pebelajar.

\section{DAFTAR PUSTAKA}

Alfindasari, D., \& Surahman, E. (2014). Sumber daya manusia dan pendidikan di era global: sebuah tinjauan terhadap penelitian teknologi pendidikan di LPTK. In Proceeding Seminar Nasional 
Teknologi Pembelajaran. Yogyakarta: UNY.

Arikunto, S. 2013. Dasar Dasar Evaluasi Pendidikan. Bumi Aksara: Jakarta.

Borg, Walter. R. \& Gall, M., D. (1989). Educational research: an introduction $4^{\text {th }}$ Edition. New Logman: London.

Bradshaw, Z., \& Hazell, A. (2017). Developing problem-solving skills in mathematics: a lesson study. International Journal for Lesson and Learning Studies.

Budiningsih, A. 2007. Karakteristik Siswa sebagai Pijakan Pembelajaran. UNY Press: Yogyakarta.

Budiningsih, A. 2008. Desain Pesan Pembelajaran. FIP UNY: Yogyakarta.

Car, L. T., Kyaw, B. M., Dunleavy, G., Smart, N. A., Semwal, M., Rotgans, J. I., ... \& Campbell, J. (2019). Digital problembased learning in health professions: systematic review and meta-analysis by the Digital Health Education Collaboration. Journal of medical Internet research, 21(2), e12945.

Chen, C. H., \& Yang, Y. C. (2019). Revisiting the effects of project-based learning on students' academic achievement: A meta-analysis investigating moderators. Educational Research Review, 26, 71-81.

Dewi, I. N., Poedjiastoeti, S., \& Prahani, B. K. (2017). Elsii learning model based local wisdom to improve students' problem solving skills and scientific communication. International Journal of Education and Research, 5(1), 107-118.

Joe Lio Tjoe. (2013). Peningkatan Kemampuan Membaca Permulaan melalui Pemanfaatan Multimedia. Jurnal Pendidikan Usia Dini, 7 (1), 17-48.

Kaya, D., İzgiol, D., \& Kesan, C. (2017). The Investigation ofelementarymathematics teacher candidates' problem solving skills according to various variables. International Electronic Journal of Elementary Education, 6(2), 295-314.

Kinay, I., \& Bagçeci, B. (2016). The Investigation of the Effects of Authentic Assessment Approach on Prospective Teachers' Problem-Solving Skills. International Education Studies, 9(8), 51-59.

Kozikoglu, I. (2019). Investigating Critical
Thinking in Prospective Teachers: Metacognitive Skills, Problem solving Skills and Academic Self-Efficacy. Journal of Social Studies Education Research, 10(2), 111-130.

Mathew, R., Malik, S. I., \& Tawafak, R. M. (2019). Teaching Problem solving Skills using an Educational Game in a Computer Programming Course. Informatics in Education, 18(2), 359373.

Matlin, W, M. 1989. Cognition $2^{\text {nd }}$ Edition. Holt Rineheart and Winston Inc: New York.

Mayer, R, E. 2009. Multimedia Learning $2^{\text {nd }}$ Edition. Cambridge University Press.

Mulyasa, E. 2009. Praktik Penelitian Tindakan Kelas. PT. Remaja Rosdakarya: Bandung.

Noorjanah, L. (2014). Pengembangan Profesionalisme Guru melalui Penulisan Karya IImiah bagi Guru Profesional di SMA Negeri 1 Kauman Kabupaten Tulungagung. Jurnal Humanity, 10 (1), 97-114.

Paramita, A. \& Kristiana, L. (2013). Teknik Focus Group Discussion dalam Penelitian Kualitatif. Buletin Penelitian Sistem Kesehatan, 16 (2), 117-127.

Patnani, M. (2013). Upaya Meningkatkan Kemampuan Problem solving pada Mahasiswa, 1 (2), 130-142.

Purwanti, A. (2015). Pengembangan Motion Graphic Pembelajaran Mata Pelajaran Pendidikan Kewarganegaraan Kelas I Sekolah Dasar. Jurnal Inovasi Teknologi Pendidikan, 2 (2), 189-200.

Riyanto., Arifin, A. S., \& Ardiansyah, B. (2017). Penerapan Media Karikatur Berbasis Sparkol Video Scribe untuk Meningkatkan Hasil Belajar Kornetif pada Matakuliah Genetika Mahasiswa Biologi Kelas A Angkatan 2014 KelasIBU. Edubiotik, 2 (2), 18-25.

Silmi, M. Q., \& Rachmadiyanti, P. (2018). Pengembangan Media Pembelajaran Video Animasi Berbasis Sparkol Videoscribe tentang Persiapan Kemerdekaan RI di SD Kelas V. JPGSD, 6 (4), 486-495.

Smaldino, S. E., et al. 2015. Instructional Technology and Media for Learning $11^{\text {th }}$ Edition. Pearson: USA. 
Sulasamono, B. S. (2012). Problem solving: Signifikansi, Pengertian, dan Ragamnya. Satya Widya, 28 (2), 156-165.

Surahman, E., Wedi, A., Soepriyanto, Y., \& Setyosari, P. (2018, December). Design of Peer Collaborative Authentic Assessment Model Based on Group Project Based Learning to Train Higher Order Thinking Skills of Students. In International Conference on Education and Technology (ICET 2018). Atlantis Press.

Surahman, E., Kuswandi, D., \& Wedi, A. (2019, December). Students' Perception of Project-Based Learning Model in Blended Learning Mode Using Sipejar. In International Conference on Education Technology (ICOET 2019). Atlantis Press.
Suyantiningsih., \& Wahyuningsih, D. (2017). The Development of Multimedia Based Whiteboard Animation Technique to Improve Teachers'Capability in Implementing Classroom Action Research.Proceding:The $2^{\text {nd }}$ Intenational Conference on Learning Inovation ad Quality Education, $2^{\text {nd }}$ Edition, 884-889, 28 Oktober 2017, Surakarta, UNS.

Yudha, F. S. A., Asrul., \& Kamus, Z. (2016). Pembuatan Bahan Ajar Fisika Berbasis Video menggunakan Sparkol Videoscribe untuk Pembelajaran Fisika Siswa Kelas X SMA. Pillar of Physics Education, 8, 153-160. 